\title{
Doses of Phosphorus in Monoammonium Phosphate form Incorporated in Biodegradable Polymers for Corn
}

\author{
Mayara M. Martins ${ }^{1}$, Marcelo C. M. Teixeira Filho ${ }^{2}$, Fernando S. Galindo ${ }^{2}$, Salatiér Buzetti ${ }^{2}$, José A. Malmonge ${ }^{3}$ \\ \& Luiz F. Malmonge ${ }^{3}$ \\ ${ }^{1}$ School of Agriculture "Luiz de Queiroz", São Paulo University, Piracicaba, SP, Brazil \\ ${ }^{2}$ Department of Plant Health, Rural Engineering, and Soils, College of Engineering, Sao Paulo State University, \\ Ilha Solteira, SP, Brazil \\ ${ }^{3}$ Department of Physics and Chemistry, College of Engineering, Sao Paulo State University, Ilha Solteira, SP, \\ Brazil \\ Correspondence: Fernando S. Galindo, Department of Plant Health, Rural Engineering, and Soils, College of \\ Engineering, Sao Paulo State University (UNESP), Ilha Solteira, SP, Brazil. Tel: 55-(18)-98120-8054. E-mail: \\ fs.galindo@yahoo.com.br
}

Received: January 7, 2018

Accepted: February 3, $2018 \quad$ Online Published: March 15, 2018

doi:10.5539/jas.v10n4p316

URL: https://doi.org/10.5539/jas.v10n4p316

\begin{abstract}
The use of monoammonium phosphate (MAP) dissolved in organic polymers can reduce the fixation of phosphorus in the soil, and thus provide greater availability of this nutrient for long-term crops. The objective of this study was to evaluate the effect of doses of phosphorus in conventional form and incorporated MAP in biodegradable polymers, evaluating nutritional status, production components and corn grain yield, as well as the residual effect of $\mathrm{P}$ and $\mathrm{N}$. The experiment was conducted in a no- tillage system consolidated for more than 10 years in a Latossolo Vermelho distrófico (Oxisol) with a clay texture located in Selvíria, MS, Brazil. The experimental design was a randomized block design with four replicates, arranged in a $4 \times 4$ factorial scheme, four forms of MAP (conventional, P1 = polymers with $30 \%$ MAP + water, P2 = polymers with $70 \%$ MAP + water and $\mathrm{P} 3=$ polymers with $30 \%$ of MAP), and four doses of $\mathrm{P}_{2} \mathrm{O}_{5}\left(0,60,120\right.$ and $\left.180 \mathrm{~kg} \mathrm{ha}^{-1}\right)$, applied soon after emergence of the seedlings in the corn sowing line. Polymer P1 released higher amounts of $\mathrm{P}$ to the soil up to the R1 stage of corn, also provided the highest grain yield, indicating to be the most promising for use in Brazilian Cerrado soil.
\end{abstract}

Keywords: Zea mays, phosphate fertilization, improved efficiency fertilizer, gradual release fertilizer, grain yield

\section{Introduction}

Due to its productive potential, chemical composition and nutritive value, corn (Zea mays L.) is one of the most important cultivated and consumed cereals in the world, Brazil being the third largest producer and second largest exporter in the world (Conab, 2015; Galindo et al., 2016).

Fertilization is recognized as one of the factors that favor the yield and sustainability of the activity. Among the nutrients that most affect productivity, phosphorus $(\mathrm{P})$ is one of the most limiting factors for agricultural crops, especially in tropical soils, which generally have a low P content and a predominance of acidity (Araújo, 2011), mainly due to the low utilization of phosphate fertilizers and, consequently, inadequate plant nutrition (Silva et al., 2012; Gazola et al., 2013).

In fertilizations, phosphorus is usually supplied to plants in the form of soluble phosphate fertilizers at the time of sowing, but due to their high adsorption capacity in clayed soils (aluminum and iron oxides), high doses are necessary to obtain high yields. In order to overcome the problem of the costs of soluble phosphates obtained by conventional solubilization processes, alternative sources of phosphorus have been proposed (Harger et al., 2007).

One way to reduce losses by phosphorus complexation is through gradual or controlled release of the nutrient contained in fertilizers. These fertilizers are called slow release fertilizers, such as polymerized fertilizers (Figueiredo et al., 2012; Machado \& Souza, 2012; Gazola et al., 2013). 
According to Gazola et al. (2013), the gradual release promoted by the coating of phosphate fertilizer, such as MAP (soluble source), theoretically causes the contact of the phosphorus with the $\mathrm{Fe}$ and $\mathrm{Al}$ oxides and the clay to be reduced, with a drastic reduction of the formation of compounds, which decreases the predisposition of the nutrient to be adsorbed on the soil. Therefore, the use of polymer-coated fertilizers can provide lower losses and greater availability of $\mathrm{P}$ in the soil over time, which can be absorbed by plants in production systems. They therefore require less frequent application, reducing spending on labor-work for the installment, avoid injuries to seeds and roots, arising from excessive applications, and are less susceptible to loss, minimizing the risk of environmental pollution (Silva et al., 2012).

The polymers used in the encapsulation are macromolecules that are repeated, that is, they are monomers that have in their chemical structure carbon and hydrogen. Currently, more than 10,000 polymers are known, each of which has a different behavior for the encapsulation, some have their release controlled by moisture, others by the temperature, and it is important to know the behavior of these polymers applied in fertilizers in order for the result to be satisfactory (Silva et al., 2012).

The technology of encapsulation of the sources with the use of polymers has been arousing the interest and distrust of several researchers, because its results are still controversial. In view of the above, the objective was to evaluate phosphorus doses in the form of conventional MAP and MAP incorporated in biodegradable polymers, evaluating the nutritional state, production components and corn grain yield in no-tillage system. As well as, to analyze the residual of $\mathrm{P}$ and $\mathrm{N}$ in the organic polymers.

\section{Methods}

\subsection{Field sites and Material Description}

The experiment was carried out at the Fazenda de Ensino, Pesquisa e Extensão (FEPE) at the Faculty of Engineering of Ilha Solteira, Universidade Estadual Paulista (FE/UNESP), in the municipality of Selvíria, MS, Brazil, located at $22^{\circ} 22^{\prime}$ latitude $\mathrm{S}$ and $51^{\circ} 22^{\prime} \mathrm{O}$ longitude, with an altitude of $335 \mathrm{~m}$, under field conditions.

The soil of the experimental area was characterized as a Latossolo Vermelho ditrófico (Oxisol), with a clay texture (EMBRAPA, 2013). The experiment was conducted in an area planted with annual crops for more than 27 years, with at least 10 years under no-tillage system, with the last year of fallow. The chemical attributes of the soil in the arable layer $(0-0.20 \mathrm{~m})$ determined before the installation of corn experiment, according to methodology proposed by Raij et al. (2001), presented the following results: $10 \mathrm{mg} \mathrm{dm}^{-3}$ of $\mathrm{P}$ (resin); $5 \mathrm{mg} \mathrm{dm}^{-3}$ of $\mathrm{S}_{-\mathrm{SO}_{4}} ; 22 \mathrm{~g} \mathrm{dm}^{-3} \mathrm{O} . \mathrm{M}$. (organic matter); $5.3 \mathrm{pH}\left(\mathrm{CaCl}_{2}\right) ; \mathrm{K}, \mathrm{Ca}, \mathrm{Mg}, \mathrm{H}+\mathrm{Al}=2.4 ; 21.0 ; 18.0$ and $28.0 \mathrm{mmol}_{\mathrm{c}}$ $\mathrm{dm}^{-3}$, respectively; $\mathrm{Cu}, \mathrm{Fe}, \mathrm{Mn}, \mathrm{Zn}(\mathrm{DTPA})=3.2 ; 22.0 ; 24.2$ and $1.2 \mathrm{mg} \mathrm{dm}^{-3}$, respectively; $0.16 \mathrm{mg} \mathrm{dm}^{-3} \mathrm{~B}$ (hot water) and $60 \%$ base saturation.

The climate according to Köppen's classification is the fundamental type Aw, humid tropical with a rainy season in the summer and dry in the winter, and the average annual rainfall was $1370 \mathrm{~mm}$. The values of rainfall and air temperature recorded during the conduction of the experiment are shown in Figure 1.

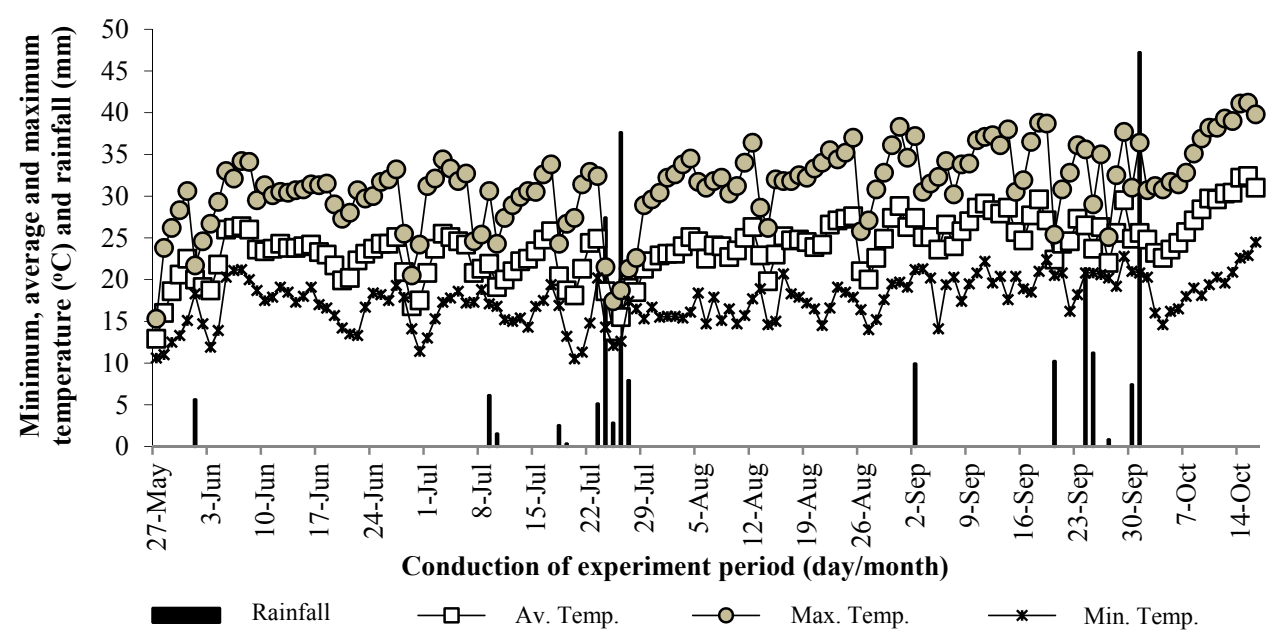

Figure 1. Rainfall, average, maximum and minimum temperature recorded during the conduction of the experiment. Selvíria, MS, Brazil, 2014 


\subsection{Experimental Design}

The experimental design was a randomized complete block design with four replicates, arranged in a $4 \times 4$ factorial scheme: 4 MAP forms (conventional MAP with $22.71 \% \mathrm{P}, \mathrm{P} 1=30 \% \mathrm{MAP}+$ water polymers, $4.13 \% \mathrm{P},=\mathrm{P} 2$ polymers of MAP $+70 \%$ water with $6.48 \%$ of $\mathrm{P}$ and $\mathrm{P} 3=30 \%$ of polymers with MAP, with $5.53 \%$ of $\mathrm{P}$ ), in 4 doses of $\mathrm{P}_{2} \mathrm{O}_{5}\left(0,60,120\right.$ and $\left.180 \mathrm{~kg} \mathrm{ha}^{-1}\right)$ applied soon after emergence of seedlings in the corn sowing line. Useful plots were $4 \mathrm{~m}$ in length with 4 rows spaced $0.45 \mathrm{~m}$.

The preparation of the organic polymers was based on a greenhouse research, in which the organic polymer with dissolved urea (C1) was more efficient than the conventional urea when applied to the soil surface, providing a higher corn dry matter yield (Souza et al., 2016). After elaboration of the organic polymers based on rubber latex in the Department of Physics and Chemistry of UNESP, Câmpus de Ilha Solteira, these were cut and standardized with about $2 \mathrm{~mm}$ thickness and $0.50 \mathrm{~cm}^{2}$.

After 15 days of desiccation of the weed of the area with glyphosate $\left(1500 \mathrm{~g} \mathrm{ha}^{-1}\right.$ of a.i. (active ingredient)), the corn hybrid DKB 350 PRO (resistant to the carcass caterpillar-Spodoptera frugiperda) was sown, with a $0.45 \mathrm{~m}$ in between lines and using 3.3 seeds per meter, on May 27, 2014, and then the area was irrigated by means of a central pivot with a water slide of approximately $14 \mathrm{~mm}$ to promote seed germination. Seedling emergence occurred 5 days after sowing.

In the sowing fertilization, $80 \mathrm{~kg} \mathrm{ha}^{-1}$ of $\mathrm{K}_{2} \mathrm{O}$ (Potassium Chloride) and $1 \mathrm{~kg} \mathrm{ha}^{-1}$ of $\mathrm{B}$ (Boric Acid) were applied to all treatments, based on soil analysis and irrigated corn requirement, as described by Cantarella et al. (1997). Considering that conventional MAP has $10 \%$ of N, P1 has $2.85 \%$ of N, P2 has $4.22 \%$ of N and P3 has $3.69 \%$ of $\mathrm{N}$, nitrogen fertilization of sowing has been equalized and complemented in the form of urea, according to each treatment, applying the dose of $54 \mathrm{~kg} \mathrm{ha}^{-1}$ of $\mathrm{N}$. Sowing fertilization was performed soon after the emergence of the first seedlings, around 10 days after sowing. During the application of organic polymers, carried out in the seedling line of corn crop, it was observed that the soil was moist due to the irrigation carried out in the area, a propitious condition for the hydrolysis of the fertilizers.

For weed control, the herbicides tembotrione $\left(84 \mathrm{~g} \mathrm{ha}^{-1}\right.$ of a.i. $)$ and atrazine $\left(1000 \mathrm{~g} \mathrm{ha}^{-1}\right.$ of a.i.) were applied, plus the addition of an adjuvant in the herbicide syrup, vegetable oil ( $720 \mathrm{~g} \mathrm{ha}^{-1}$ of a.i.) in post-emergence, in corn stage of V2 (two leaves completely unfolded).

When corn plants were in the V6 stage (six leaves completely unfolded), the nitrogen top-dressing fertilization was performed with $80 \mathrm{~kg} \mathrm{ha}^{-1}$ of $\mathrm{N}$, in the form of urea, between the lines of the plots. The area was irrigated to minimize $\mathrm{N}$ losses by volatilization of the ammonia. Irrigation during the conduction of the experiment was performed by means of a central pivot, with a mean depth of $14 \mathrm{~mm}$, also for all treatments, with irrigation shift of approximately two days, according to the crop need. After 122 days (10/16/2014) of emergence of the seedlings, the corn spikes were harvested.

\subsection{Analytical Procedures}

The following evaluations were performed: a) $\mathrm{N}$ and $\mathrm{P}$ foliar concentrations determined according to methodology proposed by Malavolta et al. (1997), the average 20-leaf third of the main stem insertion was collected in the female flowering of corn plants, according to the methodology described in Cantarella et al. (1997); b) leaf chlorophyll index (LCI) at the flowering stage of the crop, being determined indirectly by the portable chlorophyllometer readings in the leaf below the main ear (in the middle third of this corn leaf); c) height of plants at maturity, defined as being at a distance $(\mathrm{m})$ from the ground level to the apex of the tassel and d) stem diameter, measured using a pachymeter, in $\mathrm{cm}$. Ten representative spikes of corn were collected at the time of harvest for counting: e) length and f) ear diameter; $g$ ) number of grains per spike; h) mass of 100 grains, determined in precision scale $0.01 \mathrm{~g}$, at $13 \%$ (wet basis); i) grain yield, determined by the collection of the spikes of the plants contained in the useful lines of each plot. After the mechanical track, the grains were quantified and the data transformed in $\mathrm{kg} \mathrm{ha}^{-1}$ to $13 \%$ (wet basis) and $\mathrm{j}$ ) Evaluation of the residual effect and release of nutrients of polymers, collected at the time of flowering.

Data were submitted to analysis of variance (Test F) and the means of MAP forms were compared by the Tukey test at $5 \%$ probability and, for the effect of $\mathrm{P}_{2} \mathrm{O}_{5}$ doses adjusted to regression equations, using the SISVAR program. 


\section{Results and Discussion}

\subsection{Nutritional, Productive Components and Corn Grain Yield}

The monoammonium phosphate (MAP) forms did not differ in the values of LCI (foliar chlorophyll index), N and $\mathrm{P}$ foliar concentrations, number of grains per spike, length and diameter of spikes, plant height, stem diameter and 100 grains mass (Table 1), similarly to the results reported by Gazola et al. (2013), working with four residual doses of $\mathrm{P}_{2} \mathrm{O}_{5}\left(0,50,100\right.$ and $\left.150 \mathrm{~kg} \mathrm{ha}^{-1}\right)$, and four sources (conventional monoammonium phosphate (MAP) and MAP coated by three different polymers).

Table 1. Leaf chlorophyll index (LCI), leaf concentrations of nitrogen ( $\mathrm{N}$ foliar) and phosphorus ( $\mathrm{P}$ foliar), number of grains per spike, length and diameter of spike, plant height, stem diameter, 100 grains mass and corn grain yield, as a function of MAP forms and doses of $\mathrm{P}_{2} \mathrm{O}_{5}$. Selvíria, MS, Brazil, 2014

\begin{tabular}{|c|c|c|c|c|c|c|c|c|}
\hline Treatments & LCI & $\mathrm{N}$ foliar & P foliar & \multicolumn{2}{|c|}{$\begin{array}{l}\text { Number of grains } \\
\text { per spike }\end{array}$} & \multicolumn{2}{|c|}{ Spike length } & Spike diameter \\
\hline & & \multicolumn{4}{|c|}{-------- g kg $^{-1}$} & \multicolumn{3}{|c|}{----------------- cm ---------------- } \\
\hline \multicolumn{9}{|l|}{ MAP form } \\
\hline $\mathrm{P} 1$ & $46.10 \mathrm{a}$ & $25.11 \mathrm{a}$ & $2.94 \mathrm{a}$ & \multicolumn{2}{|l|}{$525 \mathrm{a}$} & $15.31 \mathrm{a}$ & & $4.61 \mathrm{a}$ \\
\hline P2 & $46.72 \mathrm{a}$ & $26.82 \mathrm{a}$ & $2.95 \mathrm{a}$ & \multicolumn{2}{|l|}{$512 \mathrm{a}$} & $15.35 \mathrm{a}$ & & $4.63 \mathrm{a}$ \\
\hline P3 & $48.72 \mathrm{a}$ & $26.70 \mathrm{a}$ & $2.86 \mathrm{a}$ & \multicolumn{2}{|l|}{$531 \mathrm{a}$} & $16.14 \mathrm{a}$ & & $4.65 \mathrm{a}$ \\
\hline MAP & $47.63 \mathrm{a}$ & $25.52 \mathrm{a}$ & $2.93 \mathrm{a}$ & \multicolumn{2}{|l|}{$533 \mathrm{a}$} & $15.63 \mathrm{a}$ & & $4.61 \mathrm{a}$ \\
\hline DMS & 8.07 & 4.44 & 0.36 & \multicolumn{2}{|l|}{70.18} & 1.47 & & 0.17 \\
\hline \multicolumn{9}{|c|}{$\mathrm{P}_{2} \mathrm{O}_{5} \operatorname{doses}\left(\mathrm{kg} \mathrm{ha}^{-1}\right)$} \\
\hline 0 & $47.51^{(1)}$ & $27.70^{(2)}$ & $3.20^{(3)}$ & \multicolumn{2}{|l|}{490} & $14.55^{(4)}$ & & $4.48^{(5)}$ \\
\hline 60 & 48.49 & 26.23 & 2.90 & \multicolumn{2}{|l|}{544} & 16.25 & & 4.64 \\
\hline 120 & 49.36 & 25.66 & 2.80 & \multicolumn{2}{|l|}{541} & 16.28 & & 4.69 \\
\hline 180 & 43.80 & 24.61 & 2.76 & \multicolumn{2}{|l|}{525} & 15.35 & & 4.69 \\
\hline Overall Mean & 47.29 & 26.05 & 2.91 & \multicolumn{2}{|l|}{525} & 15.61 & & 4.62 \\
\hline C.V. $(\%)$ & 7.92 & 8.22 & 5.15 & \multicolumn{2}{|l|}{14.17} & 10.01 & & 4.00 \\
\hline \multirow[t]{2}{*}{ Treatments } & \multicolumn{2}{|c|}{ Plant height } & \multicolumn{2}{|l|}{ Stem diameter } & \multicolumn{2}{|c|}{100 grains mass } & \multicolumn{2}{|c|}{ Grain Yield } \\
\hline & \multirow{2}{*}{\multicolumn{2}{|c|}{----------- $m$------------ }} & \multirow{2}{*}{\multicolumn{2}{|c|}{-------- cm -------- }} & \multicolumn{2}{|c|}{------------ g ----------- } & --- & --- $\mathrm{kg} \mathrm{ha}^{-1}$------- \\
\hline \multicolumn{5}{|l|}{ MAP form } & & & & \\
\hline $\mathrm{P} 1$ & \multicolumn{2}{|l|}{$2.31 \mathrm{a}$} & \multicolumn{2}{|l|}{$2.29 \mathrm{a}$} & \multicolumn{2}{|l|}{$23.78 \mathrm{a}$} & \multicolumn{2}{|c|}{$6024 \mathrm{a}$} \\
\hline $\mathrm{P} 2$ & $2.33 \mathrm{a}$ & & $2.27 \mathrm{a}$ & & $22.29 \mathrm{a}$ & & 458 & $9 \mathrm{~b}$ \\
\hline P3 & $2.34 \mathrm{a}$ & & $2.24 \mathrm{a}$ & & $22.42 \mathrm{a}$ & & 452 & $7 \mathrm{~b}$ \\
\hline MAP & $2.31 \mathrm{a}$ & & $2.28 \mathrm{a}$ & & $22.28 \mathrm{a}$ & & 479 & $5 \mathrm{~b}$ \\
\hline DMS & 0.06 & & 0.19 & & 2.95 & & 803 & \\
\hline $\mathrm{P}_{2} \mathrm{O}_{5}$ doses $(\mathrm{kg}$ & & & & & & & & \\
\hline 0 & 2.30 & & 2.30 & & 22.94 & & 400 & $8^{(6)}$ \\
\hline 60 & 2.33 & & 2.31 & & 23.78 & & 524 & \\
\hline 120 & 2.32 & & 2.24 & & 22.56 & & 530 & \\
\hline 180 & 2.33 & & 2.23 & & 22.50 & & 537 & \\
\hline Overall Mean & 2.32 & & 2.27 & & 22.94 & & 498 & \\
\hline C.V. $(\%)$ & 2.22 & & 7.42 & & 13.63 & & 17. & \\
\hline
\end{tabular}

Note. Means followed by letters equal, in the column, do not differ by Tukey test, at $5 \%$ probability. $\mathrm{P} 1=$ latex-based polymer with 30\% MAP dissolved in water, P2 = latex-based polymer with 70\% MAP dissolved in water, $\mathrm{P} 3=$ latex-based polymer with $30 \%$ MAP.

${ }^{1 \mathrm{LCI}} \mathrm{Y}=47.1940+0.0646 \mathrm{x}-0.0005 \mathrm{x}^{2}\left(\mathrm{R}^{2}=0.88^{* *}\right.$ and P.M. $=64.6 \mathrm{~kg} \mathrm{ha}^{-1}$ of $\left.\mathrm{P}_{2} \mathrm{O}_{5}\right) ;{ }^{2 \mathrm{~N}} \mathrm{Y}=27.5276-0.0162 \mathrm{x}$

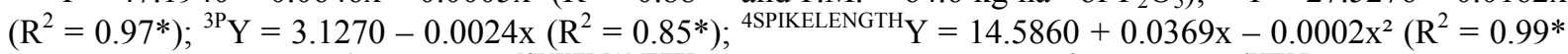
and P.M. $=92.3 \mathrm{~kg} \mathrm{ha}^{-1}$ of $\left.\mathrm{P}_{2} \mathrm{O}_{5}\right)$; ${ }^{\text {5SPIKEDIAMETER }} \mathrm{Y}=4.5219+0.0011 \mathrm{x}\left(\mathrm{R}^{2}=0.79^{*}\right) ;{ }^{6 \text { YIELD }} \mathrm{Y}=4067.0000+$ $21.6490 \mathrm{x}-0.0819 \mathrm{x}^{2}\left(\mathrm{R}^{2}=0.95^{*}\right.$ and $\mathrm{PM}=132.2 \mathrm{~kg} \mathrm{ha}^{-1}$ of $\left.\mathrm{P}_{2} \mathrm{O}_{5}\right)$. 
For grain yield, the MAP polymerized form $\mathrm{P} 1$ provided higher value compared to other polymers (P2 and P3) and to the conventional MAP (Table 1), 23.8; 24.8 and 20.4\% higher than the polymers P2 and P3 and conventional MAP respectively, and although the other parameters evaluated did not differ in the form of MAP, the mass of 100 grains was the productive component that most influenced the increment in yield provided by the polymer P1 with values $6.27,5.72$ and $6.31 \%$ higher compared to the polymers $\mathrm{P} 2, \mathrm{P} 3$ and conventional MAP, respectively.

In the same study region, Valderrama et al. (2011), noted that the coated triple superphosphate did not differ from conventional triple superphosphate, for production of components and yield of irrigated corn, in no-tillage soil with a medium phosphorous content $\left(31 \mathrm{mg} \mathrm{dm}^{-3}\right)$. However, Figueiredo et al. (2012) found that polymer-coated MAP promoted better corn performance with respect to yield, total dry matter mass and plant height compared to conventional MAP at base saturation levels of 40 and $50 \%$.

In turn, Guareschi et al. (2011) found that the application of $\mathrm{KCl}$ and triple superphosphate, polymer coated, 15 days before sowing propitiated higher dry matter yield, number of pods per plant and higher soybean grain yield, in relation to these fertilizers in conventional forms, demonstrating the importance of the study on polymerized fertilizers in different localities in Brazil.

The effectiveness of the coated fertilizers depends on the solubility of the polymer coating the granule and the hydrolysis, which will regulate the nutrient supply process (Mello et al., 2017). These rates of release and dissolution of water-soluble fertilizers depend on the coating materials (Rodrigues et al., 2013). According to these authors, the nutrient release will depend on soil temperature and humidity, which in the present case presented high temperatures and low precipitation, as shown in Figure 1.

Moreover, the thickness and chemical nature of the coating resin, the amount of microcracks on its surface and the size of the fertilizer granules, determine the rate of release of nutrients over time (Rodrigues et al., 2014), therefore, the fact that the polymer is made of latex may have influenced the release of $\mathrm{P}_{2} \mathrm{O}_{5}$. Thus, there is still a need for new researches to develop new polymers for MAP coating that can withstand the high temperatures common in this region of the low altitude Cerrado. It is noteworthy that the results with MAP coated by polymers can vary according to the season of application of the fertilization and the climatic conditions in the period of this application.

In relation to the $\mathrm{P}_{2} \mathrm{O}_{5}$ doses, there was influence in the LCI, and in the $\mathrm{N}$ and $\mathrm{P}$ leaf concentrations, with adjustment to the quadratic function with maximum dose point in approximately $65 \mathrm{~kg} \mathrm{ha}^{-1}$ of $\mathrm{P}_{2} \mathrm{O}_{5}$ for LCI and adjustment to the linear function decreasing for the concentrations of $\mathrm{N}$ and $\mathrm{P}$, that is, the increase of the doses of $\mathrm{P}_{2} \mathrm{O}_{5}$ reduced the concentrations in the foliar tissue of these nutrients (Table 1). Possibly, the results obtained occurred due to the nutrients dilution effect, caused by the greater accumulation of dry matter of the corn plant.

According to Cantarella et al. (1997), the appropriate ranges for the foliar concentrations of $\mathrm{N}$ and $\mathrm{P}$, are, respectively, 27-35 and 2.0-4.0 $\mathrm{g} \mathrm{kg}^{-1}$, therefore, it is verified that the concentration of $\mathrm{P}$ in the leaves was adequate for all treatments (Table 1), while $\mathrm{N}$ concentration, on average, was slightly below the range of sufficiency. It is also emphasized that phosphate fertilization, both with conventional MAP and polymerized MAPs, provided phosphorus for corn crop.

$\mathrm{P}_{2} \mathrm{O}_{5}$ doses also influenced the spike length and diameter and corn grain yield. For spike diameter was set to linear increasing function, and the length of spike and yield, the increase of these parameters occur until a dose of approximately 92 and $132 \mathrm{~kg} \mathrm{ha}^{-1} \mathrm{P}_{2} \mathrm{O}_{5}$ (Table 1), confirming the importance of phosphorus for ear formation and grain filling, in a soil with low initial content of this nutrient. One of the possible explanations of the obtained results is due to the conduction of the experiments in no-tillage system, which provides an increase of the organic matter content and greater activity of the soil microbiota (Souza et al., 2010), besides the $\mathrm{pH}$ of the soil is corrected and these conditions interfere positively in the non-fixation of $\mathrm{P}$ and increasing its availability in the soil for corn plants.

Similar results were obtained by Gazola et al. (2013), which obtained an increase in productivity of corn kernels to $120 \mathrm{~kg} \mathrm{ha}^{-1}$ of $\mathrm{P}_{2} \mathrm{O}_{5}$, near the maximum calculated dose obtained in this work (around $132 \mathrm{~kg} \mathrm{ha}^{-1} \mathrm{P}_{2} \mathrm{O}_{5}$ ). However, Valderrama et al. (2011), did not verify the effect of phosphorus doses applied at sowing $(0,40,80$ and $120 \mathrm{~kg} \mathrm{ha}^{-1}$ of $\mathrm{P}_{2} \mathrm{O}_{5}$ ) on corn grain yield under no-tillage, probably due to irrigated cultivation, average $\mathrm{P}$ content $\left(31 \mathrm{mg} \mathrm{dm}^{-3}\right)$ in the soil, and the possible low P requirement of the corn hybrid used.

According to Gazola et al. (2013) for corn crop, with respect to the removal of nutrients, phosphorus is almost all translocated to the grains ( 80 to $90 \%$ ). In addition, according to the authors, for each ton of grain produced by 
this crop, $10 \mathrm{~kg}$ of $\mathrm{P}_{2} \mathrm{O}_{5}$ are exported, which justifies the decrease of this content in the leaf, as well as the higher yields due to the increase of $\mathrm{P}_{2} \mathrm{O}_{5}$ doses, mainly due to the low content of this nutrient in the soil $\left(10 \mathrm{mg} \mathrm{dm}^{-3}\right)$.

\subsection{Residual Analysis of Polymers}

Table 2 shows the residual $\mathrm{N}$ and $\mathrm{P}$ contents evaluated by means of the collection of the polymers ( 74 days after the application of the polymers in the experimental area, at the R1 stage, corn female flowering), used to estimate the amount of nutrients released during the period.

Table 2. Residual $\mathrm{N}$ and $\mathrm{P}$ contents of MAP organic polymers collected at the time of corn leaf collect for nutritional diagnosis (R1 stage). Selvíria, MS, Brazil, 2014

\begin{tabular}{lll}
\hline MAP form & N content $(\%)$ & P content $(\%)$ \\
\hline P1 ${ }^{(i)}$ & 1.23 & 0.84 \\
P2 & 1.17 & 1.51 \\
P3 & 0.96 & 1.00 \\
\hline
\end{tabular}

Note. $\mathrm{P} 1=$ latex-based polymer with $30 \% \mathrm{MAP}$ dissolved in water, $\mathrm{P} 2=$ latex-based polymer with $70 \% \mathrm{MAP}$ dissolved in water, P3 = latex-based polymer with 30\% MAP.

In the P1 polymer there was the highest $\mathrm{N}$ content and the lowest $\mathrm{P}$ content in relation to the P2 and P3 polymers (Table 2), explaining why the polymer P1 provided the highest corn grain yield, that is, there was a higher release of $\mathrm{P}$ in the the initial phase of corn growth, a period in which nutrient absorption is very important for the development of the plant. In addition, the higher $\mathrm{N}$ content in the R1 stage may have contributed to nitrogen nutrition in the grain filling stage, as shown by the larger mass of 100 grains provided by the polymer P1, which had a positive effect on corn grain yield.

\section{Conclusions}

The increase of $\mathrm{P}_{2} \mathrm{O}_{5}$ doses positively influenced LCI, length and ear diameter. Corn grain yield increased with increasing of $\mathrm{P}_{2} \mathrm{O}_{5}$ doses up to approximately $132 \mathrm{~kg} \mathrm{ha}^{-1}$, irrespective of MAP coated or not by organic polymers.

The latex-based polymer with 30\% MAP dissolved in water released larger amounts of P and less than N to the soil up to the R1 stage of corn, relative to the latex-based polymer with 70\% MAP dissolved in water and latex base with 30\% MAP. The polymer less concentrated in $\mathrm{P}$ and with addition of water to the latex provided the highest corn grain yield, indicating, therefore, to be the most promising for agricultural use in Brazilian Cerrado soil.

\section{References}

Araújo, F. F. (2011). Disponibilização de fósforo, correção do solo, teores foliares e rendimento de milho após a incorporação de fosfatos e lodo de curtume natural e compostado. Acta Scientiarum. Agronomy, 33(2), 355-360. https://doi.org/10.4025/actasciagron.v33i2.1021

Cantarella, H., Raij, B. van, \& Camargo, C. E. O. (1997). Cereais. In B. van Raij, H. Cantarella, J. A. Quaggio, \& A. M. C. Furlani (Eds.), Recomendações de calagem e adubação para o Estado de São Paulo. Boletim Técnico, 100 (p. 285). Campinas: Instituto Agronômico de Campinas.

CONAB (Companhia Nacional de Abastecimento). (2015). Acompanhamento da safra brasileira de grãos (Vol. 2, No. 10, pp. 1-109). Brasília. Retrieved from http://www.conab.gov.br/OlalaCMS/uploads/arquivos/ 15_07_09_08_59_32_boletim_graos_julho_2015.pdf

Embrapa (Empresa Brasileira de Pesquisa Agropecuária). (2013). Sistema Brasileiro de Classificação de Solos (3rd ed., p. 353). Brasília, DF: Embrapa, Centro Nacional de Pesquisa de Solos.

Figueiredo, C. C., Barbosa, D. V., Oliveira, S. A., Fagioli, M., \& Sato, J. H. (2012). Adubo fosfatado revestido com polímero e calagem na produção e parâmetros morfológicos de milho. Revista Ciência Agronômica, 43(3), 446-452. https://doi.org/10.1590/S1806-66902012000300005

Galindo, F. S., Teixeira Filho, M. C. M., Buzetti, S., Santini, J. M. K., Alves, C. J., Nogueira, L. M., ... Bellote, J. L. M. (2016). Corn yield and foliar diagnosis affected by nitrogen fertilization and inoculation with Azospirillum brasilense. Revista Brasileira de Ciência do Solo, 40(1), 1-18. https://doi.org/10.1590/ 18069657 rbcs 20150364 
Gazola, R. N., Buzetti, S., Dinalli, R. P., Teixeira Filho, M. C. M., \& Celestrino, T. S. (2013). Efeito residual da aplicação de fosfato monoamônio revestido por diferentes polímeros na cultura de milho. Revista Ceres, 60(6), 876-884. https://doi.org/10.1590/S0034-737X2013000600016

Guareschi, R. F., Gazolla, P. R., Perin, A., \& Santini, J. M. K. (2011). Adubação antecipada na cultura da soja com superfosfato triplo e cloreto de potássio revestidos por polímeros. Revista Ciência e Agrotecnologia, 35(4), 643-648. https://doi.org/10.1590/S1413-70542011000400001

Harger, N., Brito, O. R., Ralisch, R., Ortiz, F. R., \& Watanabe, T. S. (2007). Avaliação de fontes e doses de fósforo no crescimento inicial do milho. Semina: Ciências Agrárias, 28(1), 39-44. https://doi.org/10.5433/ 1679-0359.2007v28n1p39

Machado, V. J., \& Souza, C. H. E. (2012). Disponibilidade de fósforo em solos com diferentes texturas após aplicação de doses crescentes de fosfato monoamônico de liberação lenta. Bioscience Journal, 28(1), 1-7.

Malavolta, E., Vitti, G. C., \& Oliveira, S. A. (1997). Avaliação do estado nutricional das plantas: Princípios e aplicações (2nd ed., p. 319). Piracicaba: Potafos.

Mello, T., Buzetti, S., Teixeira Filho, M. C. M., Galindo, F. S., \& Nogueira, L. M. (2017). Residual effects of nitrogen fertilizer with polymer-coated urea in a corn crop. Revista Caatinga, 30(3), 586-594. https://doi.org/10.1590/1983-21252017v30n306rc

Raij, B. van, Andrade, J. C., Cantarella, H., \& Quaggio, J. A. (2001). Análise química para avaliação da fertilidade de solos tropicais (p. 285). Campinas: IAC.

Rodrigues, M. A. C., Buzetti, S., Maestrelo, P. R., Lino, A. C. M., Teixeira Filho, M. C. M., Andreotti, M., \& Garcia, C. M. P. (2013). Cloreto de potássio revestido em efeito residual no feijoeiro de inverno irrigado na região de Cerrado. Semina: Ciências Agrárias, 34(3), 1011-1022. https://doi.org/10.5433/1679-0359.2013 v34n3p1011

Rodrigues, M. A. C., Buzetti, S., Teixeira Filho, M. C. M., Garcia, C. M. P., \& Andreotti, M. (2014). Adubação com $\mathrm{KCl}$ revestido na cultura do milho no Cerrado. Revista Brasileira de Engenharia Agrícola e Ambiental, 18(2), 127-133. https://doi.org/10.1590/S1415-43662014000200001

Silva, A. A., Silva, T. S., Vasconcelos, A. C. P., \& Lana, R. M. Q. (2012). Influência da aplicação de diferentes fontes de MAP revestido com polímeros de liberação gradual na cultura do milho. Bioscience Journal, 28(1), 240-250.

Souza, F. H. Q., Teixeira Filho, M. C. M., Galindo, F. S., Malmonge, L. F., Malmonge, J. A., \& Buzetti, S. (2016). Doses de nitrogênio e modos de aplicação de polímeros orgânicos com ureia dissolvida na cultura do milho. Cultura Agronômica, 25(4), 361-372.

Souza, R. F., Faquin, V., Sobrinho, R. R. L., \& Oliveira, E. A. B. (2010). Influência de esterco bovino e calcário sobre o efeito residual da adubação fosfatada para a Brachiaria brizantha cultivada após o feijoeiro. Revista Brasileira de Ciência do Solo, 34(1), 143-150. https://doi.org/10.1590/S0100-06832010000100015.

Valderrama, M., Buzetti, S., Benett, C. G. S., Andreotti, M., \& Teixeira Filho, M. C. M. (2011). Fontes e doses de NPK em milho irrigado sob plantio direto. Pesquisa Agropecuária Tropical, 41(2), 254-263. https://doi.org/10.5216/pat.v41i2.8390

\section{Copyrights}

Copyright for this article is retained by the author(s), with first publication rights granted to the journal.

This is an open-access article distributed under the terms and conditions of the Creative Commons Attribution license (http://creativecommons.org/licenses/by/4.0/). 